Igor E. Svetlov

Doctor of Arts, Professor

Honorary Member of the Russian Academy of Arts

Honored Worker of Culture of Poland

Lecturer Surikov Moscow Art Institute

Lecturer Academy of Slavic Culture

Leading Researcher at the State Institute of Art Studies

Head of the Inter-Institute Scientific Group "European Symbolism and Art Nouveau"

e-mail: svetlovi.e@yandex.ru

Moscow, Russia

Researchers ID AAF-3506-2019

ORCID ID 0000-0002-0943-0408

DOI: $10.36340 / 2071-6818-2019-15-4-108-135$

\title{
Hungarian Sculpture of the Late Twentieth Century. At the Intersection of Romanticism and Pop Art
}

Summary. Developing intensively and in its own way throughout the $20^{\text {th }}$ century, Hungarian sculpture has gained recognition as one of the leading European schools. Much in its creative image was determined between the two world wars when romantic tonality, combining dynamic activity and plastic flexibility, became a high priority. Romantic pantheism made itself felt in the artistic works of the Hungarians, successfully shown at the All-Union Art Exhibition in Moscow in 1957-1958. The appeal to the motives and forms of nature enriched the human modulus of Hungarian sculpture.

The period between 1960-1970 is its most fruitful time. The combination of romantic concepts and themes with object textures and aesthetics of simplicity, inherent in pop art, among the masters of the older generation, Imre Varga and Erzsébet Schaár who were recognized in Europe, was the biggest event among the variants of its creative movement. Imre Varga's evolution in this direction, from grotesque-naturalistic publicism to the use of pop art techniques as a means of the dramatic theatricalization of human life and history, is illustrated in the article. Varga developed a synthesis of the pop art-inspired landscape and romantic portrait in the best monuments of these decades.

In Erzsébet Schaár's art, the objective world more than once turned into an artistic metaphor of independent significance. However, for her, the most important meeting of romanticism and pop art happened, the same as for Varga, in the search for synthesis and the creation of an ensemble. Her Street, which is exhibited in the city of Pecs, is perceived as a combination of symbolic figures and environmental objects, imbued with the idea of infinity of the world.

Keywords: Art, sculpture, architecture, tradition, composition, form, indoor sculpture, monument, texture, bronze, plaster, foam plastic, modeling, Imre Varga, Erzsébet Schaár.

Romantic moods in Hungarian sculpture of the twentieth century were often compared to an explosion; they were sometimes balanced by the memory of antiquity 


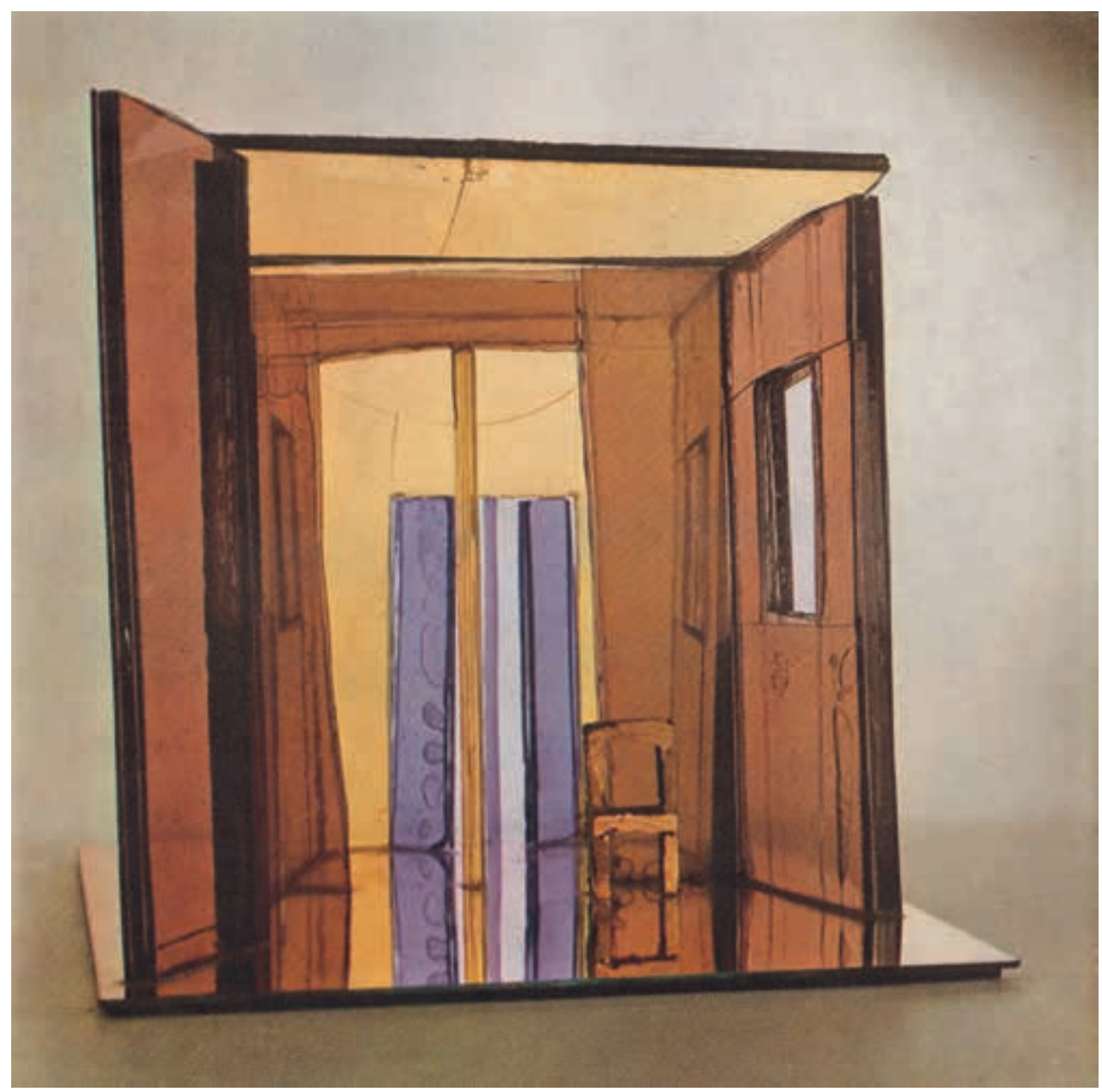

Mirror and bronze. 1969. Bronze and glass. $34,5 \times 44 \times 31,5 \mathrm{~cm}$

or the intensification of genre motifs. However, they increasingly started to become the core of its creative development especially in the second half of the century. Maybe due to the fact that the secret life of sculpture, which was almost entirely concentrated in indoor sculpture (modest in size statuettes and chamber memorials) during the interwar period, was absorbing fusion of expression and harmony, penetrated by a romantic upsurge which turned out to be historically long-lasting. Naturally, one cannot forget about other variants of the romantic search in Hungarian sculpture, from a heroic appeal to the archaic and to the lyrical dissolution inspired by the "Brussels". Nevertheless, the pre-war advance of such artists as Laszlo Messaros, Dezso Bokros-Birman, who returned to Hungary from the USSR after the 1936 amnesty, Beni Ferenczy, as well as György Goldman and Tibor Vilt - socially oriented and interestingly experimenting masters, echoed with the artistic development of the twentieth century most of all. Their 
invocations coexisted with lyrical contemplation, lonely daydreaming with collective enthusiasm, utmost composure with the admiration of natural rhythms of life. ${ }^{12}$

The Second World War gave the romantic activity of Hungarian sculpture a dynamic contrast which the heavyweight naturalism, which took place during the years of the Rákosi dictatorship (the late 1940s and mid-1950s), could not spoil. However, romantic pantheism made itself felt in works of Hungarian sculptors of different generations exhibited at the All-Union Art Exhibition in Moscow Manege in 1957-195. At that time, it had no analogy in the art of the commonwealth except for the paintings of the Vietnamese, whose panoramic landscape thinking organically incorporating the rhythms of rural labour had ancient traditions, and for Bulgarian artist Vladimir Dimitrov-Maistora's paintings which combined a monumental portrait and natural background as if a vital structure. The appeal to the motives and forms of nature enriched the human modulus of Hungarian sculpture, which had been preserved for almost the entire twentieth century, as well as its commitment to figurative art.

The romantic colour of Hungarian sculpture also showed itself in another aspect of artistic thinking: in the organic combination of a passionate desire to go forward with the animation of the distant past by art discoveries. In it, open, borderless dynamism was often accompanied by the loving mastering of the Greek archaic, the decorative rhythms of ancient Egypt, the structural ideas of baroque and classicism. The perception of the history of mankind as something inextricable and at the same time an impulsive experience of its time added an exciting poetic inspiration to the romantic direction of Hungarian sculpture.

Nevertheless, many significant changes took place in it in 1960-1970. The intensive interfacing of the national romantic tradition with modern modifications of European sculpture gave birth to such difficultly compatible trends as the painterly graphic expressionism of Jenő Kerényi's late works, variants of organic art in the spirit of Jean Arp (his influence on Miklos Borsos is obvious), an original combination of attention to the aesthetics of technicism with mystical naivety in Tamas Viga's repoussé and chasing.

However, the new facets of romantic thinking were revealed especially interestingly during this period which was extremely fruitful for Hungarian sculpture in the contact of the older generation artists Imre Varga (b.1923) and Erzsébet Schaár (1908-1975) with pop art. Erzsébet Schaár created a kind of memorial to Humanity - the famous Street. On the other hand, Varga, who became famous in 1960-1970 and later crossing the pop art threshold, became famous as the author of sculptural monuments with a capacious symbolic meaning.

You would think, what can there be in common between the fantasy aspiration and the poetic grace of Hungarian sculpture and the rude demonstration of everydayness inherent in pop art? Between the cult of things supported by this trend and the theme

1. Schaār Erzsēbet Szobrāsz-Mủvēsz Kiāllītāsa Mủcsarnok. Budapest, 1970.

2. For more information on interwar Hungarian sculpture refer to I.E. Svetlov. Sculpture of Peoples' Hungary. Moscow: Nauka, 1971. Pp. 13-40. 
of the tragic fate of the personality which became the focus of Hungarian romanticism? However, in the creative reality of the sixties and seventies, everything turned out to be more complicated: attention to the image of the environment increased, an unexpected meeting of the prosaic and the poetic took place.

Not everything in this experiment immediately worked out well. Known inconsistencies marked the pairing of romantic decor inspired by a myth and program rationalism of the figurative design in one of Imre Varga's compositions. Such an impression was made by the sculpture Prometheus, an image of a metal giant moving forward with a flame above his head, exhibited at the Budapest Hall of Art in 1964. The unexpected combination of convex and concave shapes in the figure of the mythological hero and most importantly, stunning metal plates swinging above his head were all amazing. However, skeptical reflections about the connection of this image with the new technical civilization, about the extent to which the artist was tempted to connect everything to work, which was popular at that time, about the clear contradiction between the gloomy alienation of modern Prometheus, estranged from people, and Imre Varga's festive-romantic extravaganza of flame, crowning the composition, were heard at the time of the exhibition opening.

No less shock was caused by the sculptor's variations of the Invalid motif that appeared in the 1960s, reflecting his reaction to the anti-war actions of the Vietnam War veterans in the USA. It was pop art with its increased interest in object textures and aesthetics of simplicity that seemed to Varga adequate for the film which was shown around the world, photographs, demonstration of crippled soldiers with contempt throwing military awards at the steps of the Washington Capitol shown on television. Although from the point of view of stylistics, the sculptor did not show anything new here (especially against the background of American pop art), this cycle of his was a surprise for his Hungarian artistic circle. The showiness of these pop-art opuses, assertion of romantic nobility, accompanying it, was too contradictory. This change of tone did not arouse sympathy and understanding in everyone. People in Hungary did not take the distant Vietnamese epic too closely. The fiasco of great power, sacrificing its forces for the abstract concepts of geopolitics, did not become an urgent social problem. The asceticism inspired by pop art also got along poorly with national priorities ${ }^{3}$.

Imre acutely felt that following the path of simplifications step by step, he could not count on the support of the Hungarian public. As the antithesis of the grotesque placardness at the turn of the 1960s-1970s, works in which the motifs and concepts of pop art were peculiarly connected with the romantic cult of the sacrificial person appeared in his workshop. This time subject textures were convincingly used both as a means of dramatic theatricalization and in the context of thoughts about life, man, history. As a result, the pop art landscape met with a portrait lit by romantic tradition.

3. Christa Nickel. Imre Varga im Gespräch. Budapest, 1995. Pp. 13-15. 


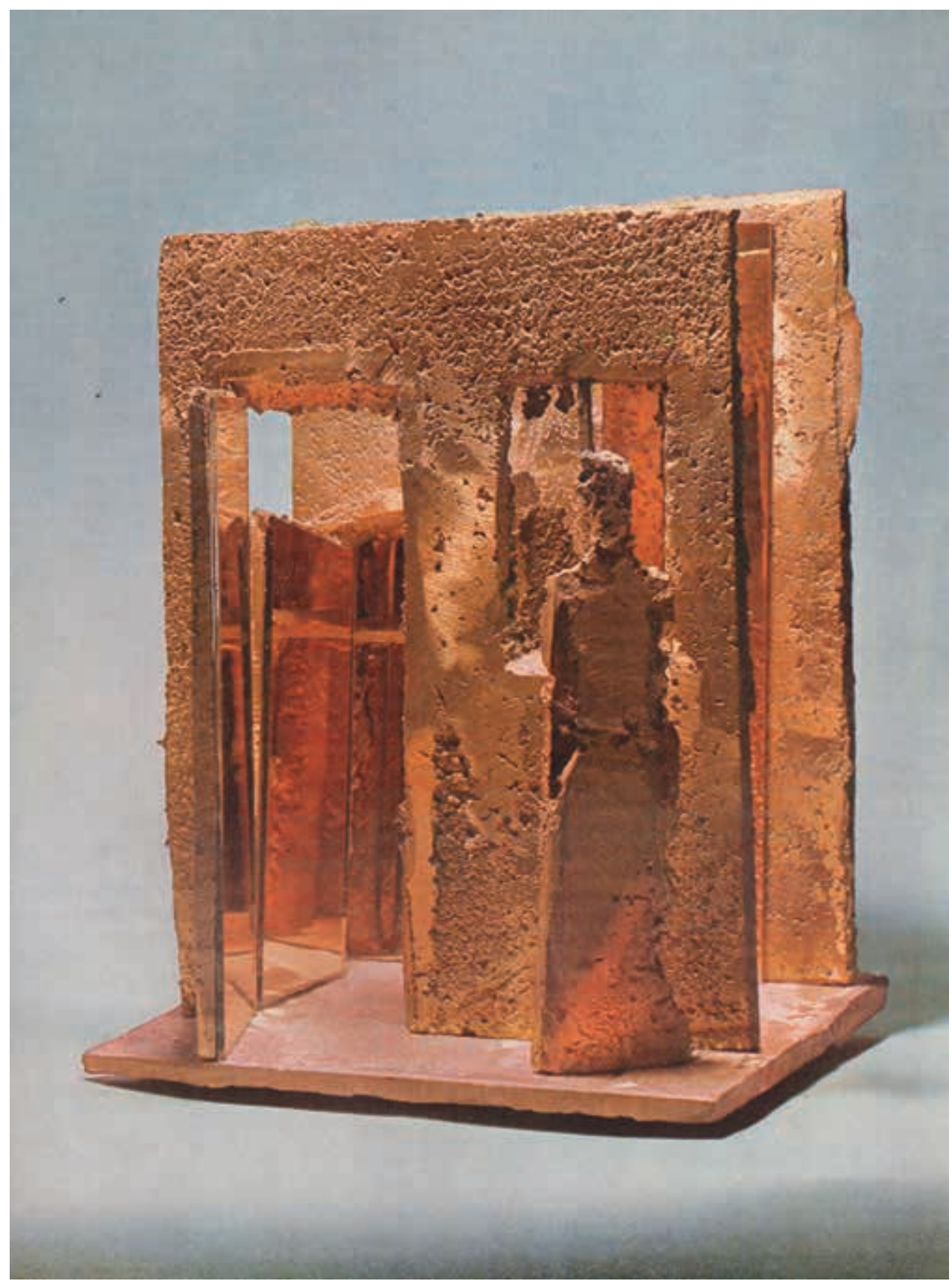

Perspective de bronze. 1972. Bronze and glass. $37,5 \times 30 \times 23,5 \mathrm{~cm}$ 


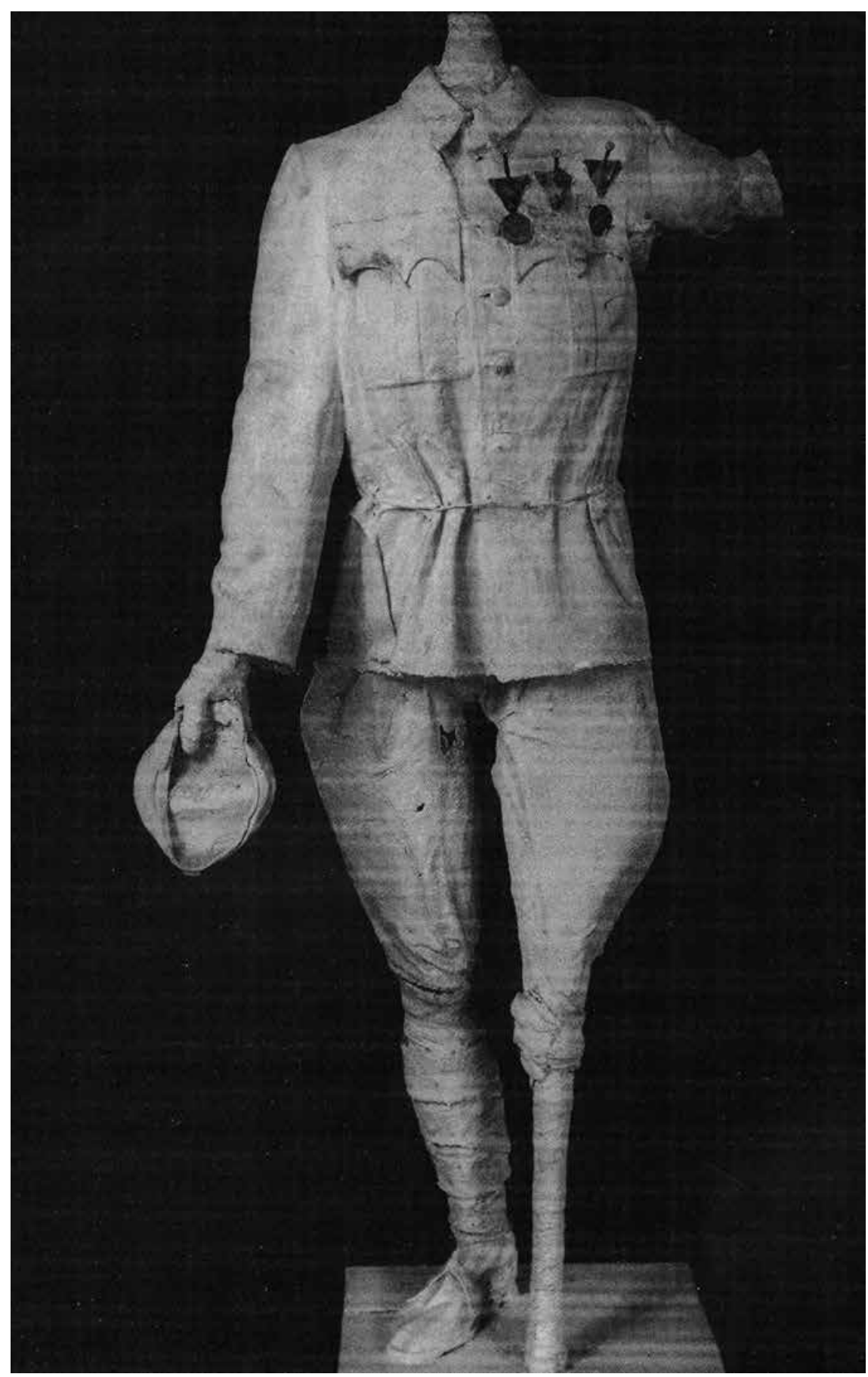

Sculptor Imre Varga. Heldendenkma. 1944, 1974, Polyester, 190 cm. Bronze Variante, OlsoNorwegen 
It is from this meeting it would be good to begin a short art criticism commentary on such sculptor's works as monuments to Gyula Derkovits (1972), one of the leaders of the Group of Socialist Artists which existed during the interwar period, to antifascist poet Miklos Radnoti (1975), and to the former president of the Republic of Hungary, Ferencz Károly (1975). All these works were preceded by expressive opuses in interior sculpture art; however, it was in the monumental genre that the reference to the forms and techniques of pop art turned out to be especially effective like spatial architecture and a historical metaphor. ${ }^{4}$

In all these monuments erected in various Hungarian cities, the action environment and its material characteristics are connected with the life situation in which the hero finds himself, with the culmination of his fate. A wooden parapet reminiscent of a scaffold, pavers evoking associations with the prison yard in the monument to Radnoti, whom the Nazis persecuted from one camp to another before killing, a panel with an attic window in the monument to Derkovich as a reminder of the atmosphere of deprivation and persecution in which the artist lived during the years of the Horthy regime, these examples are all impressive accents only sculptural art not devoid of metaphorical meanings could enter into a convincing dialogue with. Radnoti's long robe reminiscent of a chasuble and the poet's mask-like face, many poems of whom were found in camp cesspools after the war, are perceived as a mystical sacrament. The self-deepening and estrangement of this image, its elegant elevation that makes one think about the era of romanticism sharply contrast with the rough texture of heavy shoes and other signs of camp life included in the composition of the monument.

However, the elements of pop art have another function allowing you to designate the space of the memorial as a contrast of openness and isolation, while at the same time blocking the space, oriented towards the symbolic figure, from the bustle of the city, and reminding the viewer about the signs of real life.

The figure of Franz Liszt, mounted by Varga from metal forms, became the original joining of art and everyday life. Placed on one of the balconies of an old residential building in the city of Pecs (1981), it is perceived as an unusual combination of modern monumental sculpture and typical residential architecture ordinary in its appearance. The reconstruction of one of the balconies in the spirit of architectural eclecticism of the 19 th century was a notable touch of this contrast synthesis. Modest in size and turned into the apotheosis of textured banality with the help of pop art techniques, this object became the personification of the monotony of provincial life, while full of demonic energy image of Liszt leaning over the metal railing is perceived as an embodiment of the rebellion of an outstanding personality. Such an original combination of pop art and European romantic tradition reveals Imre Varga's creative concept, his conviction of the incompatibility of the everyday routine and artist's aspirations.

4. The most complete collection of Imre Varga's martyrology sketches was presented at the 41st Venice Biennale in 1984. 


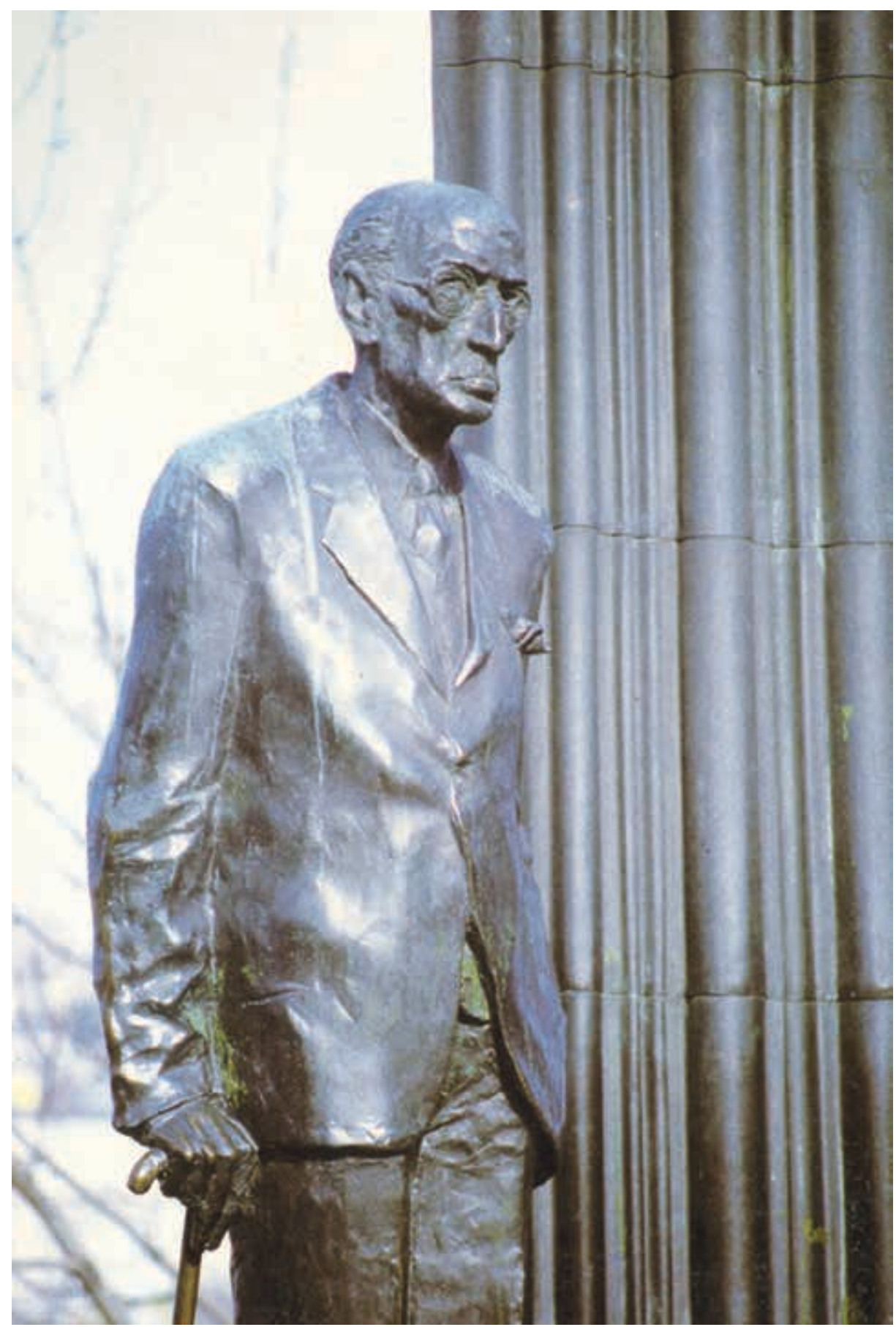

Sculptor Imre Varga. Statue of Károlyi Mihály. 1974-75. Bronze. $210 \mathrm{~cm}$. Budapest 


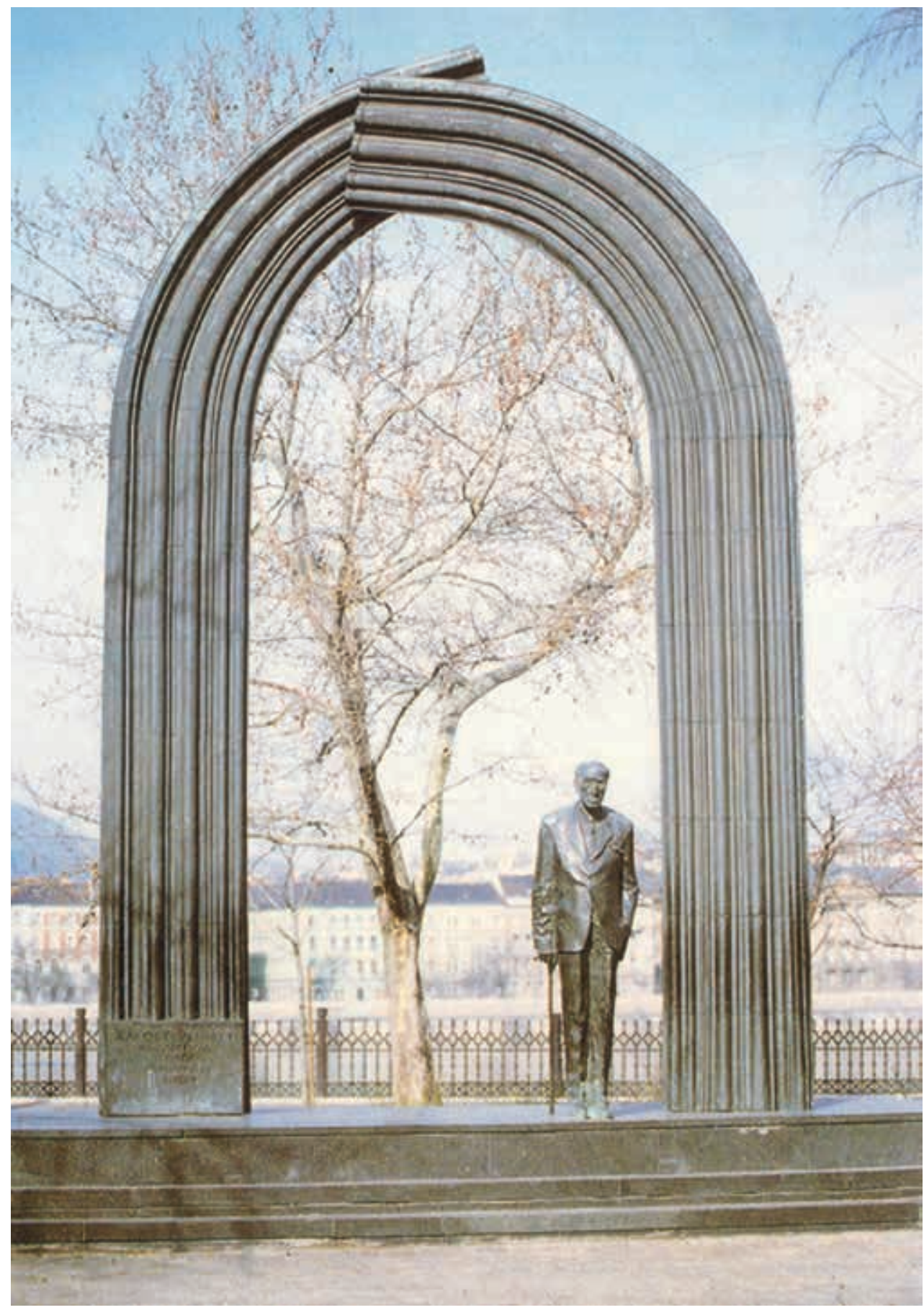

Sculptor Imre Varga. Statue of Károlyi Mihály. 1974-75. Bronze. 210 cm. Budapest. 
A romantic in his worldview, a poet of the exceptional and unusual, Varga is far from admiring the familiar surroundings of human life. Least of all was he inclined to immerse into a description of the everyday situation of people of one circle or another. A collective image of a scientist oriented to the iconography of the 18th century (Professor, 1969), dominated by the topic of the inseparability of a scientist's life and his subject environment, was an exception. A desk, a candelabrum, an inkwell, and a goose pen it seems that this is how science is done, in an atmosphere of concentration and solitude, surrounded by favourite objects and things. It is as if the figure of the old professor, transferred from the distant past, has surprisingly blended with the natural surroundings of the Middelheim park near Brussels where the largest collection of modern sculptural art in Europe is exhibited. A grassy green meadow, coniferous tree branches overshadowing the sculpture - all this reveals and sometimes, on the contrary, softens the emphasized relief of the image. In this case, unlike in the monuments to Derkovich and Radnoti, aestheticism does not compete with earthly realities but represents the time when art and exploration of the world were not alienated from each other.

Least of all was Varga inclined to exploit the principles and techniques of pop art that he had successfully tested, to repeat the same designs. A monument to the outstanding public figure of Hungary, Mihály Károlyi, is strong evidence of this. A man of unusual fate, Károlyi was not afraid to go against the prevailing circumstances, courageously behaved at the crossroads of national history. A wealthy landowner, the owner of palaces and mansions in Budapest and in other cities in Hungary, Károlyi transferred all this to the ownership of the Hungarian people. During the collapse of the Habsburg Empire, he led the democratic forces, becoming president of the Republic of Hungary. During the establishment of the Horthy fascist regime, Károlyi was forced to emigrate to France. Károlyi's second emigration was during the domination of Stalin's faithful ally Miklos Rakosi in Hungary. In the late 1940s, as ambassador to Paris, Károlyi received a call to Budapest and almost simultaneously information about his impending execution. Two arcs intersecting each other in the sky above the statue of Károlyi look like a sign of fate. Compared to the stylishly generalized forms of cathedral architecture, it is not devoid of picturesqueness; however, at the same time, the figure of Károlyi leaning on the cane, outlined in the spirit of pop art, seems particularly embossed. There is its own expression in this broken-down but still stateness figure as if it absorbed the traces of fate's trials. Such an impression is made by the combination of a chamber portrait incorporating the texture of pop art with abstract symbolism of architecture. ${ }^{5}$

\section{$* * *$}

The creative search of another master of the older generation,Erzsébet Schaár, is another hypostasis of the pop art transformation of Hungarian sculpture.

5. A detailed analysis of the monument to Károlyi is given in I.E. Svetlov's book, Traditions and Innovation in the Fine Arts of the Socialist Countries. Moscow: Nauka, 1986. Pp. 185-188. 


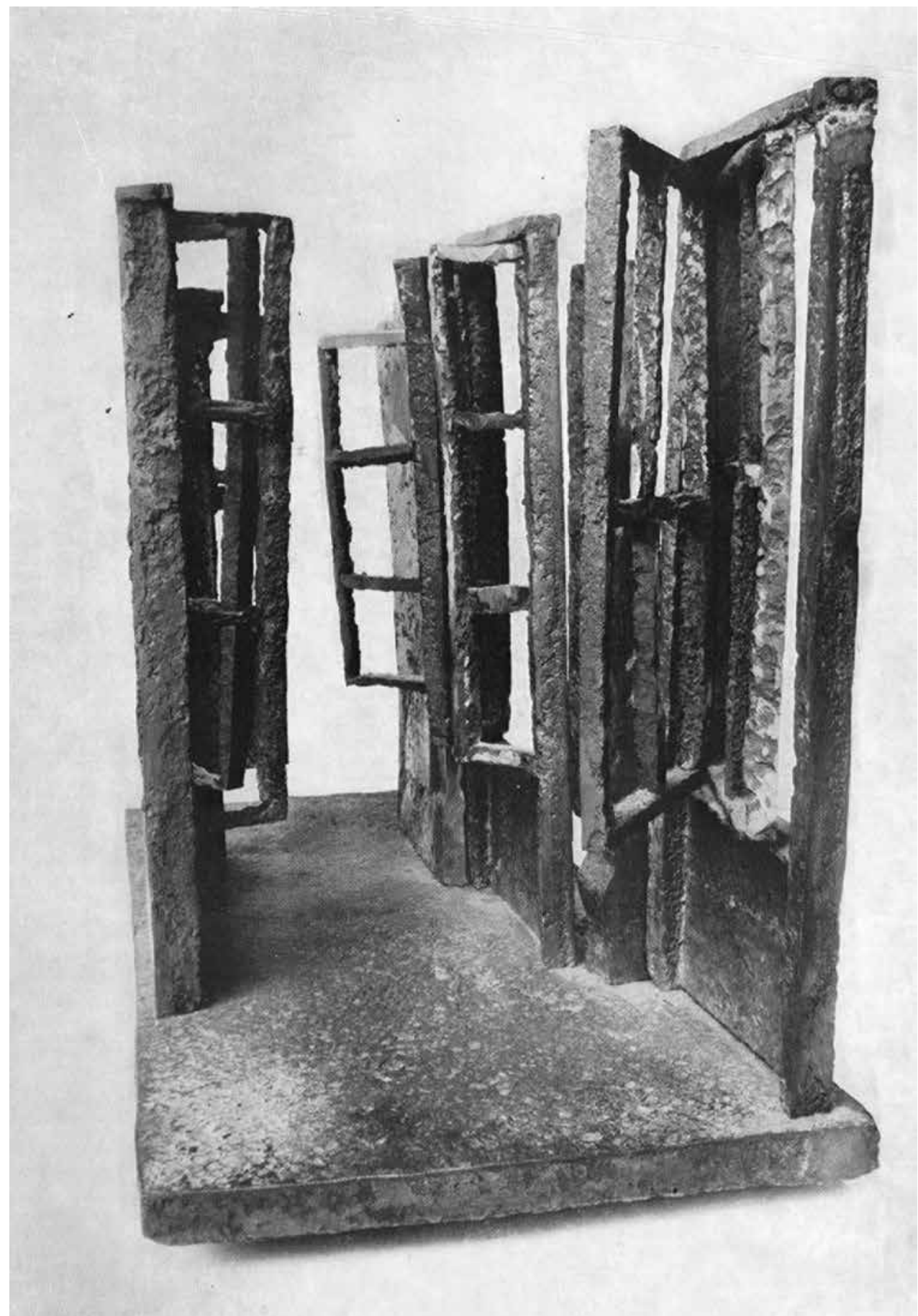

Window row. 1966. Bronze. 32,5x23,5x43 cm. 


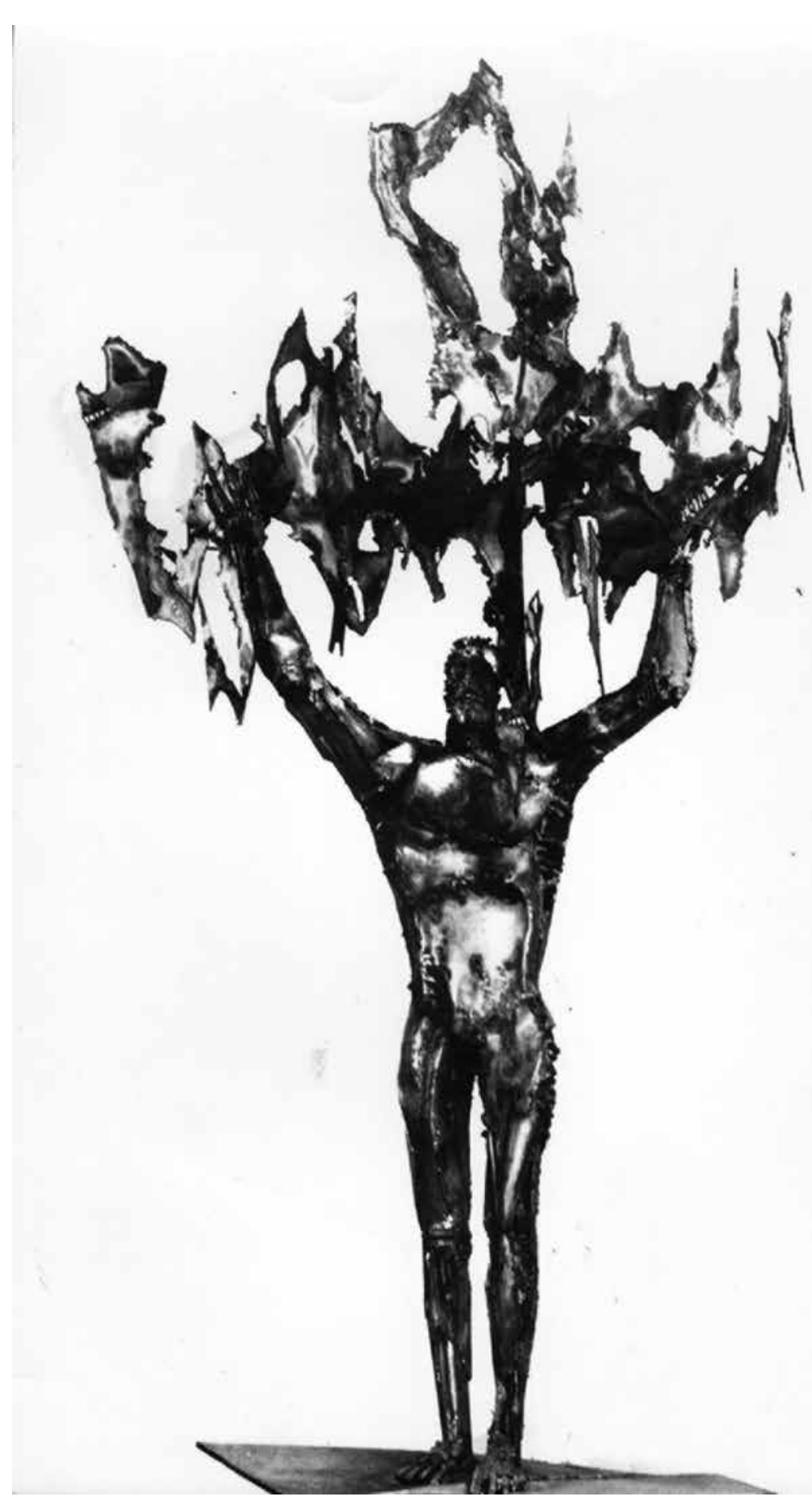

Prometheus 


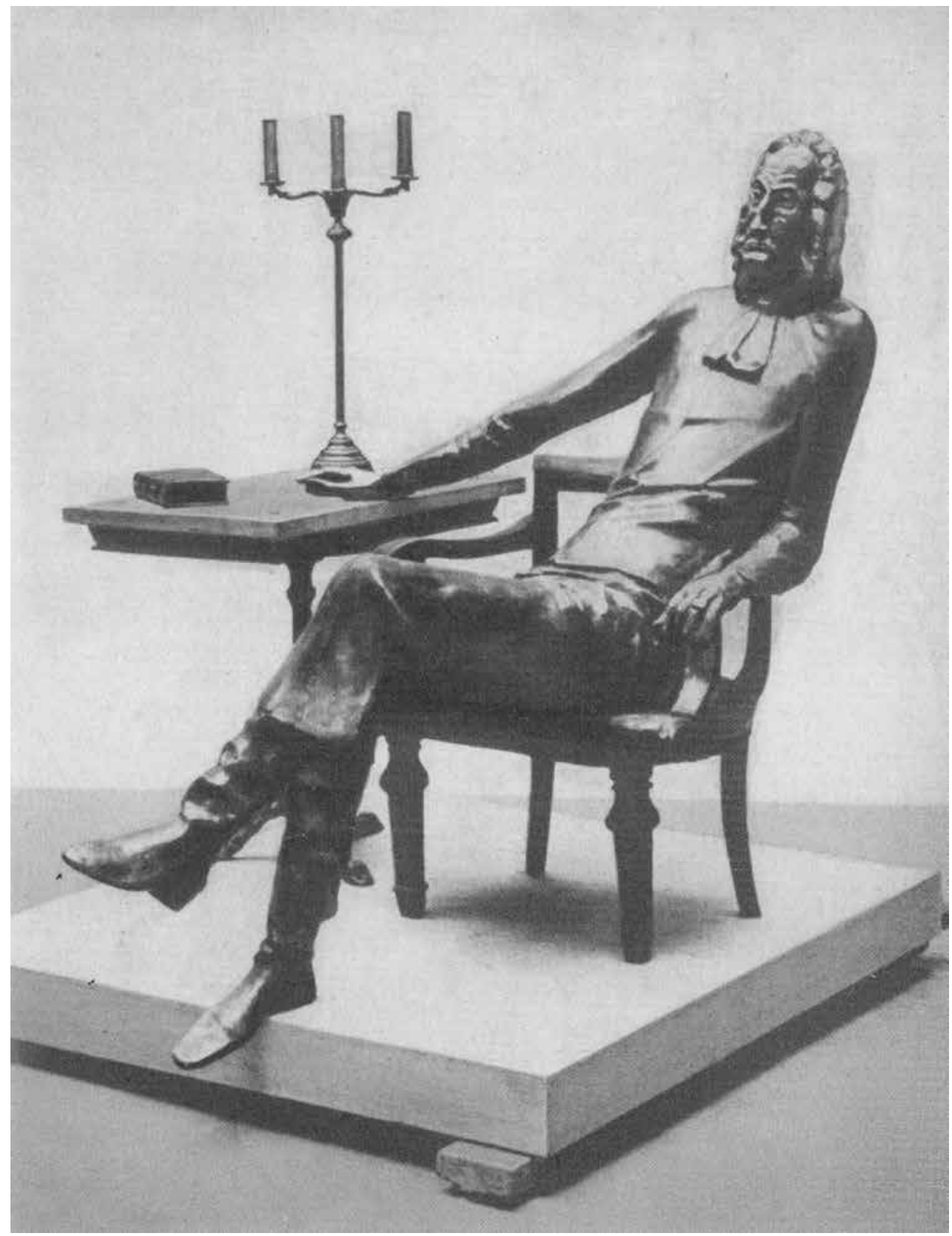

Sculptor Imre Varga. Professeur. Bronze. 1969 
In contrast to Varga, her objective world had repeatedly turned into an artistic metaphor with an independent meaning. Doors, windows, corridors, arches - all this acquired a poetic meaning for her regardless of human gestures and movements. However, like some other Hungarian sculptors, her dependence on thinking in the spirit of pop art extended to her experiments in repoussé and chasing.

In 1967, Erzsébet Schaár and Imre Varga participated in the first symposium in Hungary at the metal plant in Szekesfehervar. During one of my trips to Budapest, Imre introduced us, along with sculptor Dmitry Shakhovsky, to a documentary on the peripeteias and the result of this creative action. Of the four participants in the symposium, almost all preferred figurative solutions. In contrast, Schaár became the author of a construction made from adjacent to each other fragments of residential architecture... Against the grassy landscape stretching to the horizon, slim, ascetic, flattened in form but retaining a sense of volume, this sculpture was perceived as an embodiment of human independence and loneliness.

Creatively perceiving the influence of brutalism and pop art, Schaár understood she could relate to the concept and emotional tonality of artists of the sixties ${ }^{6}$. The composition of the doors facing each other and the windows, as if opened by the wind, expressively accorded with the situation of severe alienation attractive to this generation. Although the opponents of the artist mockingly claimed that these gloomy carcasses were picked up by her at one of the city dumps, they attracted by the noble understatement and romantic confrontation with space. Bearing in mind the genuine cult of figurativeness in Hungarian sculpture, such poetization of the subject environment was an act of considerable courage at that time.

Another point is characteristic.

Erzsébet proved to be a supporter of repoussé and chasing, popular among Hungarians, in her previous works - in the poetic female portraits preserving the memory of the war years, in the expressive reliefs, in indoor sculptures, the laboratory status of which she particularly gladly confirmed. There was a lot of intriguing in the changing balance of darkened and dazzlingly shining smooth planes, in the shocking combination of golden silhouettes and cold mirrors, in how the raw glass arrays and typical pieces of furniture combined with each other.

However, the fundamental turn lay in another fact as well. Inspired by the practice of pop art, Erzsébet turned to a completely different material - foam plastic. It would seem that the image of the latter as something lightweight, capable of changing beyond recognition at the first touch, of turning into nothing, almost disappear, and, of course, its functional connection with design tested by society can turn any sculptor away from it. Schaár just fell in love with this material, giving it a peculiar structure with an energetic block resolution and aesthetic snow-white colour.

6. Poet Geza Pernetski gave a fundamental assessment of Erzsébet Schaár's perception of pop art. Schaār Erzsēbet. Szobrāsz-Művēsz Kiāllitāsa Mủcsarnok. Budapest, 1970. Mājus 16 - jūnius 7. 


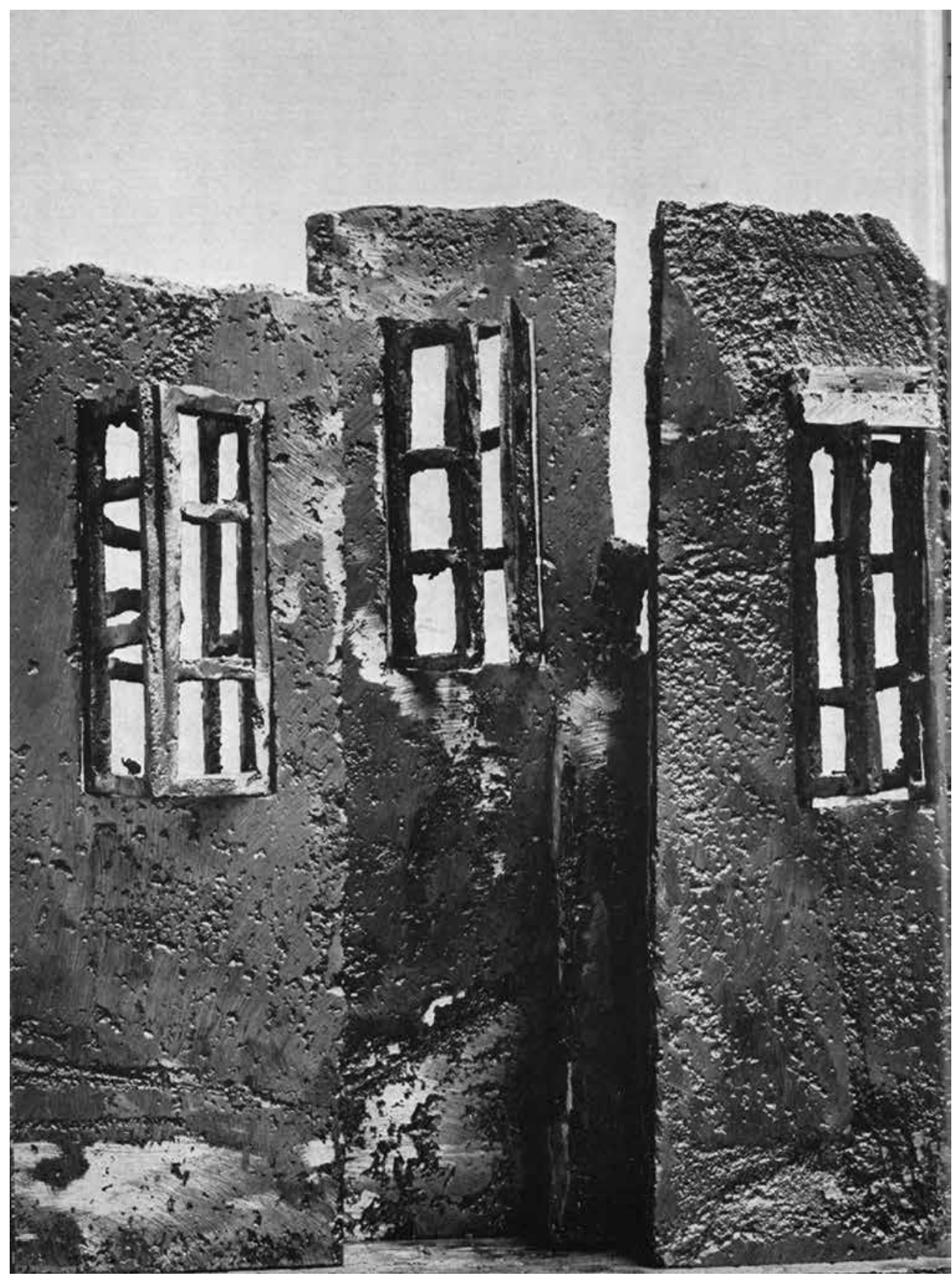

Three walls. 1968. Bronze and copper. $38 \times 35,5 \times 34 \mathrm{~cm}$ 
At first, the sculptor's opuses, which looked strange to many of her colleagues, and Schaár's subsequent attempts to use foam plastic in her monumental designs were met with skepticism. Nevertheless, gradually, her figures of young girls, drawn in the lumen of the light arches, were increasingly perceived as an expressive element of the natural landscape. One of these works, the sculpture Youth, arising like a romantic vision among the green stalls of Balaton, incorporated the poetic melancholy of a young person just starting to live. However, having received support in architecture, this symbolic composition, subtly connected with the aesthetics of pop art, is felt like a kind of split of eternity.

The idea that the complex relationship of the latter with modernity in Erzsébet Schaár's works in the last years of her life clearly dominated. The experiments that went along different lines found a vanishing point in the sculptor's most significant project the Street museum complex (1974-1975). The originality of Schaár's plan can be seen in its fundamental orientation. A series of doors and windows with busts of prominent figures of history and art placed in their openings, many symbolic figures advanced forward - all this remains as a spectacle of infinity in consciousness. Some perceive this unusual combination as an embodiment of the inexhaustibility of life, while others, on the contrary, as a memorial to the departed. But most of all, Schaár's creation is affirmed in consciousness as the living elegy of memory.

Her symbolic female images have caused many discussions. The eyebrows and jewelry patterns reminiscent of the look of modern fashionistas, bizarre outlines of the hair, all this aggravates the appearance of the figures made of foam plastic not devoid of classical allusions. Accents, having a retrospective origin but also turned to our days, give these contemplatively detached images the features of expression.

Extremely different from the movement prevailing in the Hungarian sculpture of the 1960s and 1970s, the passion for pop art intensified the creative activity of its leading masters, gave their work new features. Confirming the individual uniqueness of national romanticism, expanding its civic and philosophical context, it, at the same time, made the correlation of the image of a person with the subjective surroundings belonging to modernity and history one of the main themes. This ultimately made it possible to overcome the monopoly of figurativeness... In the best works of the luminaries of Hungarian sculpture, Imre Varga and Erzsébet Schaár, the romantic concept of the fate of a person and the fate of mankind are inseparable from the pop art-inspired vision of space and matter...

The peculiar expressiveness of objects brought into space and with characteristic features of pop art refutes the perception of this movement as a transient and ineffective experiment. The understanding of its discoveries plays an active role in the period when the idea of the monumental and the chamber is changing, and the techniques of an integrated stage direction of sculpture, architecture, and design are being formed. 


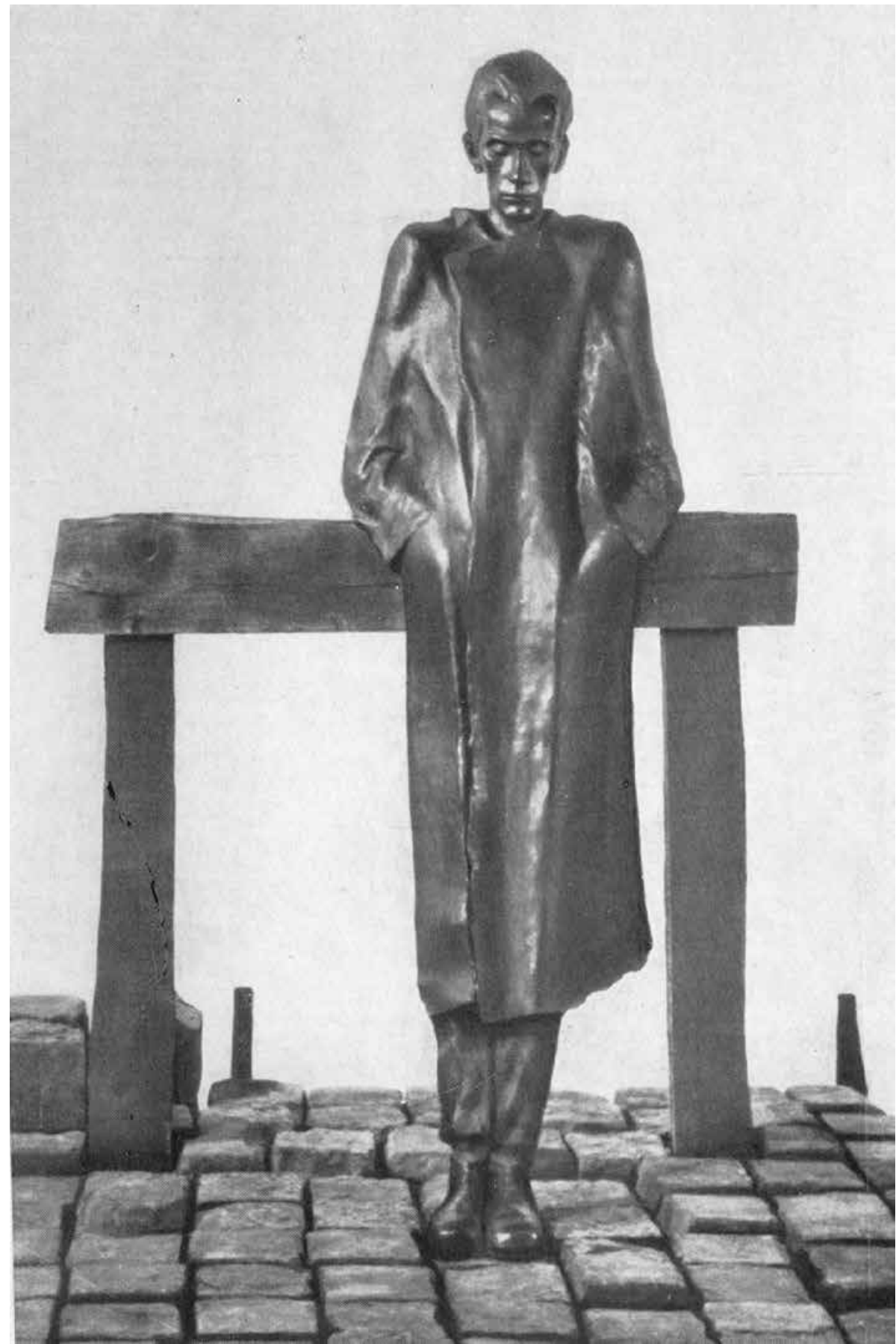

Sculptor Imre Varga. Radnoti. Bronze.1972 


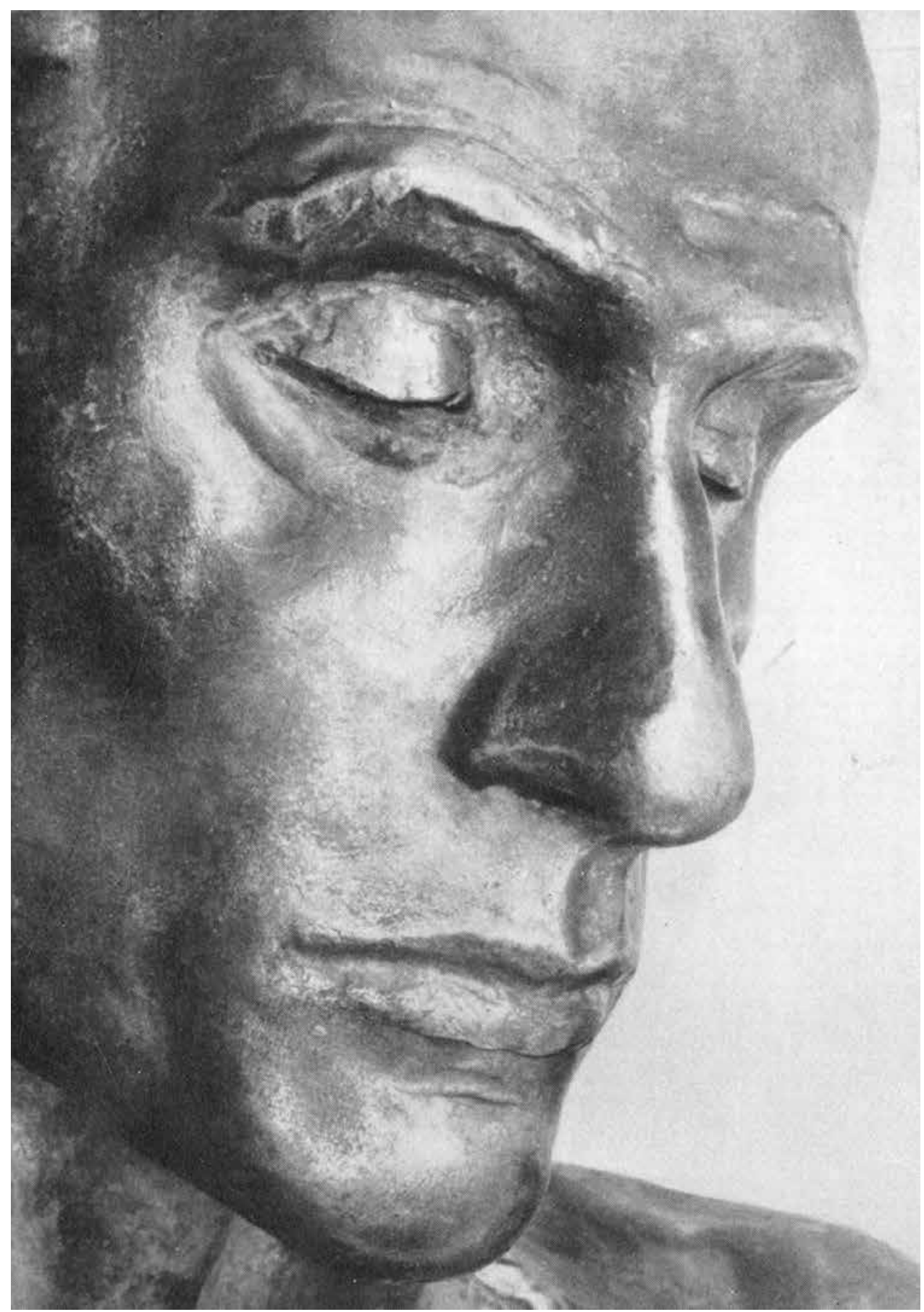

Sculptor Imre Varga. Radnoti. Fragments. Bronze.1972 


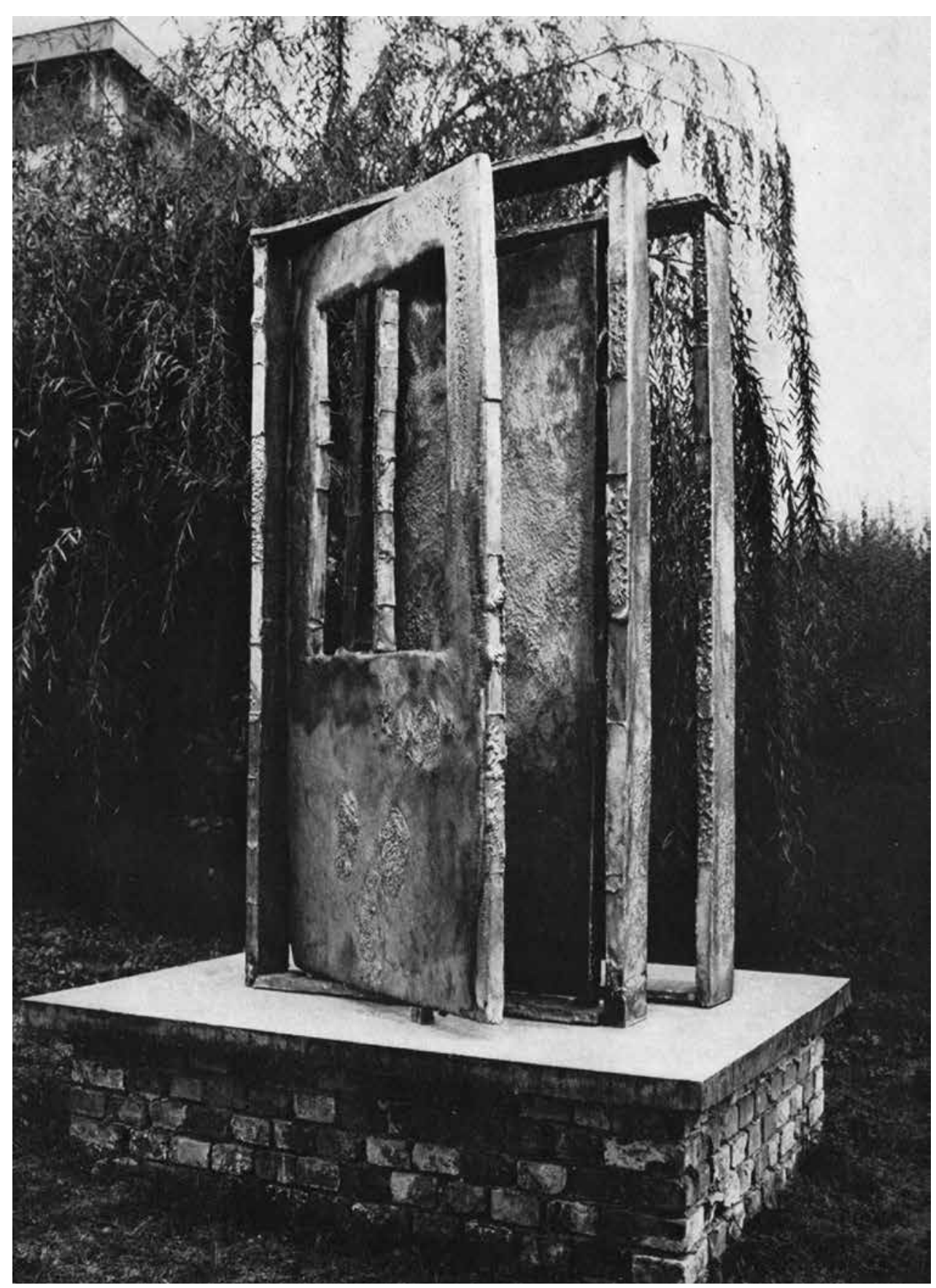

Doors. Bronze 


\section{REFERENCES}

1. Svetlov, I.E. 1970. Sculpture of People's Hungary. Moscow: Nauka

2. Svetlov, I.E. 1986. Traditions and Innovations in the Fine Arts of Socialist Countries. Moscow: Nauka

3. Soviet-Hungarian Ties in Art Culture. Compilers and editors: I.E. Svetlov, L.P. Solntseva. Moscow: Nauka, 1975.

4. Modern Hungarian Sculpture. Exhibition catalog at the Pushkin State Museum of Fine Arts. Introductory articles by Judit Baranyi, I. Svetlov. Moscow: Sovietsky Hudojnik, 1972.

5. Contemporary Hungarian Art and Literature. State Institute of Art Studies, St. Petersburg. Alethea, 2005. Editors: I. Svetlov, V. Sereda.

6. Svetlov, I.E. 1976. "Sculptor Imre Varga", Creativity, no 4, pp. 21-23

7. Svetlov, I.E. 1976. "Erzhebet Shaar: aspirations and results", Art, no 7, pp. 50-53.

8. Nickel Christa. 1995. Imre Varga im Gespräch. Budapest

9. Schaār Erzsēbet Szobrāsz-Mủvēsz Kiāllītāsa Mücsarnok. Budapest, 1970. 
Игорь Евгеньевич Светлов историк искусств, доктор искусствоведения, профессор, заслуженный деятель искусств Российской Федераичи, Почётный член Российской академии художеств, заслуженный деятель культуры Польии, преподаватель в Московском государственном академическом художественном институте имени В.И. Сурикова при Российской академии художеств и в Академии славянской культуры, ведущчий научныцй сотрудник

Государственного института искусствознания, руководитель межинститутской научной группь «Европейский символизм и модерн» e-mail: svetlov.i.e@yandex.ru Москва, Россия

ORCHID 0000-0002-0943-0408 Researcher ID AAF-3506-2019

DOI: $10.36340 / 2071-6818-2019-15-4-108-135$

\section{Венгерская скульптура конца XX века: на стыке романтизма и поп-арта}

Аннотация. Интенсивно и по-своему развиваясь на протяжении XX века, венгерская скульптура получила признание как одна из ведущих европейских школ. Многое в её творческом облике определилось в период между двумя мировыми войнами, когда решающее значение прибрела романтическая тональность, сочетающая в себе динамическую активность и пластическую гибкость. В показанных в 1957-1958 годах на Первой выставке изобразительного искусства социалистических стран в московском Манеже произведениях венгерских скульпторов разных поколений дал себя почувствовать романтический пантеизм.

Обращение к мотивам и формам природы обогатило человеческий модуль венгерской пластики. 1960-1970 годы - самое плодотворное для неё время. Среди различных вариантов творческого движения самым крупным событием стало соединение у получивших признание в Европе мастеров старшего поколения - Имре Варги и Эржебет Шаар - романтических концепций и тем с присущими поп-арту предметными фактурами и эстетикой простоты. В статье демонстрируется эволюция творческого пути Имре Варги в этом направлении - от гротескно-натуралистической публицистики к использованию приёмов поп-арта как средства драматической театрализации человеческой жизни и истории. В лучших памятниках того времени у Варги сложился синтез инспирированного поп-артом пейзажа и романтического портрета.

У Эржебет Шаар предметный мир не раз превращался в имеющую самостоятельное значение художественную метафору. Но самая главная для неё встреча 
романтизма и поп-арта возникла, как и у Варги, в поисках синтеза и создании ансамбля. Её получившая музейное бытование в городе Печ «Улица» воспринимается как проникнутое идеей бесконечности мира сочетание символических фигур и объектов материальной среды.

Ключевые слова: искусство, скульптура, дизайн, синтез, архитектура, традищия, композищия, форма, малая пластика, памятник, бронза, гипс, моделировка, Имре Варга, Эржебет Шаар.

Романтические настроения в венгерской скульптуре XX века нередко уподоблялись взрыву, порой уравновешиваясь воспоминаниями об античности или активизацией жанровых мотивов, но в то же время, особенно во второй половине столетия, всё чаще становились стержнем её творческого развития. Может быть, всё дело в том, что потаённая жизнь скульптуры, почти целиком сосредоточенная в межвоенный период в малых формах - скромных по размеру статуэтках и камерных мемориалах - вбирала в себя проникнутый романтическим подъёмом сплав экспрессии и гармонии, который оказался исторически долговечным. Однако не стоит забывать и о других вариантах романтических исканий в венгерской скульптуре - от героической апелляции к архаике до инспирированного «брюссельцами» лирического растворения. Но более всего созвучной художественному развитию XX века оказалась предвоенная поступь таких художников, как Ласло Месарош, Деже Бокрош-Бирман, вернувшийся в Венгрию из СССР после амнистии 1936 года Бени Ференци, а также Дьёрдь Гольдман и Тибор Вилт - социально ориентированных и оригинально экспериментирующих мастеров. Призывность уживалась у них с лирической созерцательностью, одинокая мечтательность - с коллективным воодушевлением, предельная собранность - с любованием естественными ритмами жизни.

Вторая мировая война придала романтике венгерской пластики динамическую контрастность, которую не смог перебить даже возникший в годы ракошистской диктатуры (конец 1940-х - середина 1950-х) тяжеловесный натурализм. Вместе с тем в показанных в 1957-1958 годах на Первой выставке изобразительного искусства социалистических стран в московском Манеже произведениях венгерских скульпторов разных поколений дал себя почувствовать романтический пантеизм. В ту пору он не имел аналогий в искусстве, исключая разве что живопись вьетнамцев, у которых панорамность пейзажного мышления, органически включавшего мотивы сельского труда, имела древние традиции, да сочетающие в себе как витальную структуру монументальный портрет и природный фон картин болгарина Владимира Димитрова-Майсторы.

Обращение к мотивам и формам природы обогащало сохранявшийся почти весь XX век человеческий модуль венгерской пластики, её приверженность к фигуративизму.

Романтический колорит венгерской скульптуры проявил себя и в другой ипостаси художественного мышления - органичном совмещении увлечённого стрем- 
ления вперёд и одушевления художественными открытиями далёкого прошлого. Открытый, не знающий оговорок динамизм часто сопровождался в ней любовным освоением греческой архаики, декоративных ритмов Древнего Египта, структурных идей барокко и классицизма. Восприятие истории человечества как чего-то неразрывного и вместе с тем - импульсивное переживание своего времени придали романтическому направлению венгерской скульптуры волнующую поэтическую окрылённость.

При этом в 1960-1970 годы в ней произошли многие знаменательные сдвиги. Интенсивное сопряжение национальной романтической традиции с современными модификациями европейской пластики дали жизнь таким трудно совместимым друг с другом тенденциям, как живописно-графический экспрессионизм позднего Енё Кереньи, варианты органического искусства в духе Арпа (очевидно его влияние на Миклоша Боршоша), оригинальное соединение внимания к эстетике техницизма и мистической наивности в металлопластике Тамаша Вига.

Особенно интересно раскрылись новые грани романтического мышления в этот исключительно плодотворный для венгерской скульптуры период в соприкосновении художников старшего поколения - Имре Варги (род. 1923) и Эржебет Шаар (1908-1975) - с поп-артом. Шаар создала своеобразный мемориал Человечеству знаменитую «Улицу». Варга же, ставший знаменитым в 1960-1970 годы, в дальнейшем перешагнув поп-артовский рубеж, прославился как автор скульптурных памятников, имеющих ёмкое символическое содержание.

Казалось бы, что может быть общего между фантазийным стремлением и поэтическим изяществом венгерской скульптуры и присущей поп-арту грубоватой демонстрацией обыденности? Между поддерживаемым этим направлением культом вещи и ставшей средоточием романтизма венгров темой трагической судьбы личности? Однако в творческой реальности шестидесятых-семидесятых всё оказалось куда сложнее: усилилось внимание к изображению окружающей среды, состоялась неожиданная встреча прозаического и поэтического.

Не всё в этом эксперименте сразу же сложилось удачно. Известными нестыковками было отмечено сопряжение вдохновлённого мифом романтического декора с программным рационализмом фигуративной конструкции в одной из композиций Имре Варги. Такое впечатление произвела показанная им в 1964 году в центральном выставочном зале Будапешта «Мючарнок» скульптура «Прометей» - изображение движущегося вперёд металлического гиганта с пламенем над головой. Неожиданная комбинация выпуклых и вогнутых форм в фигуре мифологического героя и ошеломляющее воображение качающихся над его головой металлических пластин поражали воображение. Однако уже во время открытия выставки были слышны скептические размышления о связи этого образа с новой технической цивилизацией, о том, в какой мере поддался автор искушению популярной в это время «роботизации», о явном противоречии между мрачноватой отчуждённостью отрешённого от людей со- 
временного Прометея и венчающей композицию Имре Варги празднично-романтической феерией пламени.

Не меньший шок вызвали появившиеся у скульптора в 1960-е годы вариации мотива «Инвалид», отразившие его реакцию на антивоенные выступления ветеранов Вьетнамской войны в США. Именно поп-арт с его повышенным интересом к предметной фактуре и эстетикой простоты показался Варге адекватным обошедшим весь мир кадрам кино, фотографии, телевидения с демонстрацией искалеченных солдат, с презрением бросающих свои боевые награды на ступени вашингтонского Капитолия. И хотя с точки зрения стилистики скульптор не показал здесь чего-то нового (особенно на фоне американского поп-арта), для венгерского художественного круга этот его цикл стал неожиданностью. Слишком уж явно противоречила броскость этих поп-артовских опусов сопутствовавшему ему утверждению романтического благородства. Но не у всех эта смена тона вызвала сочувствие и понимание. В Венгрии не принимали далёкую вьетнамскую эпопею слишком близко к сердцу. Фиаско великой державы, жертвующей своим воинством ради абстрактных понятий геополитики, не стало актуальной общественной проблемой. Плохо уживался с национальными приоритетами и инспирированный поп-артом аскетизм .

Имре остро почувствовал, что, шаг за шагом следуя по пути упрощений, он не может рассчитывать на поддержку венгерской публики. Как антитеза гротесковой плакатности на рубеже 1960-1970 годов в его мастерской появились произведения, в которых мотивы и концепции поп-арта оказались своеобразно связаны с романтическим культом жертвенной личности. На этот раз предметные фактуры были убедительно использованы и как средство драматической театрализации, и в контексте размышлений о жизни, человеке, истории. В итоге поп-артовский пейзаж встретился с освещённым романтической традицией портретом.

Именно с этой встречи хочется начать короткий искусствоведческий комментарий к таким произведениям скульптора, как памятники одному из лидеров существовавшей в межвоенный период «Группы социалистических художников» Дюле Дерковичу (1972), поэту-антифашисту Миклошу Радноти (1975) и бывшему президенту Венгерской Республики Ференцу Карои (1975). Все эти работы предваряли выразительные опусы в малой пластике, но именно в монументальном жанре ссылка на формы и приёмы поп-арта оказалась, как пространственная архитектура и историческая метафора, особенно действенной.

Среда действия и её вещественные характеристики во всех этих воздвигнутых в различных городах Венгрии памятниках связаны с жизненной ситуацией, в которую попадает герой, с кульминацией его судьбы. Напоминающий эшафот деревянный парапет, вызывающая ассоциации с тюремным двором брусчатка в памятнике Радноти, которого фашисты, прежде чем уничтожить, гнали из одного лагеря в другой, панель с чердачным окном в памятнике Дерковичу, как напоминание об атмосфере лишений и преследований, в которой протекала жизнь ху- 
дожника в годы хортистского режима, - всё это впечатляющие акценты, вступить в убедительный диалог с которыми могла только не лишённая метафорических значений артистическая пластика. Напоминающее ризу длинное одеяние Радноти и уподоблённое маске лицо поэта, многие стихи которого были найдены после войны в лагерных выгребных ямах, воспринимаются как мистическое таинство. Самоуглубленность и отрешённость этого изображения, заставляющая думать об эпохе романтизма элегантная возвышенность резко контрастируют с грубоватой фактурой тяжёлых башмаков и других примет лагерного обихода, включённых в композицию памятника.

Впрочем, элементы поп-арта имеют и другую функцию: они позволяют обозначить пространство мемориала как контраст открытости и замкнутости, одновременно отгораживая ориентированное на символическую фигуру пространство от суеты города и напоминая зрителю о приметах реальной жизни.

Оригинальной стыковкой искусства и повседневной жизни стала смонтированная Варгой из металлических форм фигура Ференца Листа. Размещённая на одном из балконов старого жилого здания в городе Печ (1981), она являет собой необычное сочетание современной монументальной пластики и обыденной по своему облику типовой жилой архитектуры. Примечательным штрихом этого контрастного синтеза стала реконструкция одного из балконов в духе архитектурной эклектики XIX века. Имеющий скромные масштабы и превращённый с помощью приёмов поп-арта в апофеоз фактурной банальности, этот объект стал олицетворением монотонности провинциальной жизни, тогда как полный демонической энергетики образ перегнувшегося через металлические перила Листа воспринимается олицетворением бунта незаурядной личности. Столь оригинальное сцепление поп-арта и европейской романтической традиции обнажает творческую концепцию Имре Варги, его убеждённость в несовместимости жизненной обыденности и устремлений художника.

Романтик по своему мировоззрению, поэт исключительного и необычного, Варга далёк от любования привычным антуражем человеческой жизни. Менее всего он был склонен погружаться в описание бытовой ситуации людей того или иного круга. Исключением стал ориентированный на иконографию XVIII века собирательный образ учёного («Профессор», 1969)., в котором главенствует тема неразделимости жизни учёного и окружающей его предметной среды. Письменный стол, канделябр, чернильница, гусиное перо - кажется, именно так, в атмосфере сосредоточенности и уединения, в окружении любимых предметов и вещей, и вершится наука. Фигура старого профессора, словно перенесённая из далёкого прошлого, удивительно вписалась в природное окружение парка Мидельхайм под Брюсселем, где экспонируется самая большая в Европе коллекция современной пластики на открытом воздухе. Травянистая зелёная поляна, осеняющие скульптуру ветки хвойных деревьев - всё это выявляет, а порой и смягчает подчёркнутую рельефность изображения. В данном случае, в отличие от памятников Дер- 
ковичу и Радноти, эстетизм не соревнуется с земными реалиями, а олицетворяет то время, когда искусство и исследование мира не были отчуждены друг от друга.

Меньше всего Варга был склонен эксплуатировать удачно опробованные им принципы и приёмы поп-арта, повторять одни и те же решения. Выразительное свидетельство тому - памятник выдающемуся общественному деятелю Венгрии Михаю Карои. Этот человек с необычной судьбой не боялся идти наперекор жизненным обстоятельствам, мужественно вёл себя в череде событий национальной истории. Богатый помещик, владелец дворцов и особняков в Будапеште и других городах Венгрии, Карои передал всё это в собственность венгерского народа. В период крушения Габсбургской империи он возглавил демократические силы, став президентом Венгерской Республики. Во время установления фашистского режима Хорти Карои был вынужден эмигрировать во Францию. Его вторая эмиграция пришлась на господство в Венгрии верного соратника Сталина Миклоша Ракоши. В конце 1940-х годов, будучи послом Венгрии во Франции, Карои получил вызов в Будапешт и почти одновременно - информацию о своей готовящейся казни. Две перекрещивающиеся друг над другом в небе над статуей Карои дуги символизируют знак судьбы. По сравнению со стильно обобщёнными формами соборной архитектуры, не лишённая живописности, но при этом очерченная в духе поп-арта статуя опирающегося на трость Карои кажется особенно рельефной. Есть в этой надломленной, но сохранившей статность фигуре, будто вобравшей в себя следы испытаний судьбы, особая экспрессия, Такое впечатление производит синтез вобравшего в себя фактуру поп-арта камерного портрета и абстрактного символизма архитектуры.

\section{$* * *$}

Другая ипостась поп-артовского преображения венгерской пластики - искания ещё одного мастера старшего поколения, Эржебет Шаар.

В отличие от Варги, предметный мир не раз превращался у неё в имеющую самостоятельное значение художественную метафору. Двери, окна, коридоры, арки - всё это обретало для Эржебет поэтический смысл независимо от людских жестов и движений. Но, как и у некоторых других венгерских скульпторов, зависимость от мышления в духе поп-арта распространялась у неё и на эксперименты в металлопластике.

В 1967 году Эржебет Шаар и Имре Варга участвовали в первом в Венгрии симпозиуме, прошедшем на металлическом заводе в Секешфеерваре. Во время одной из моих поездок в Будапешт Имре познакомил меня и скульптора Дмитрия Шаховского с документальным фильмом, запечатлевшим все перипетии и результат этой творческой акции. Из четырёх участников симпозиума трое отдали предпочтение фигуративным решениям. А Эржебет Шаар стала автором композиции из прилегающих друг к другу фрагментов жилой архитектуры. Стройная, аскетичная, уплощённая по формам, но в то же время сохраняющая ощущение объё- 
ма, эта пластика воспринималась на фоне стелющегося до горизонта травянистого пейзажа как олицетворение человеческой самостоятельности и одиночества.

Творчески воспринимая влияние брутализма и поп-арта, Шаар обнаружила свою близость к концепции и эмоциональной тональности художников-шестидесятников. Композиция из стоящих друг напротив друга дверей и словно распахнутых ветром окон выразительно отвечала притягательной для этого поколения ситуации жёсткого отчуждения. Хотя противники художницы издевательски утверждали, что эти мрачноватые остовы были подобраны ею на одной из городских свалок, в них привлекали благородная недосказанность и романтическое противоборство с пространством. Имея в виду подлинный культ фигуративности в венгерской скульптуре, подобная поэтизация предметной среды была в ту пору довольно смелым шагом.

В своих предшествующих сочинениях - поэтических женских портретах, сохраняющих память о переживаниях военных лет экспрессивных рельефах, в скульптуре малых форм, лабораторный статус которой она с особым удовольствием подтверждала, - Эржебет показала себя приверженцем популярной у венгров металлопластики. В меняющемся балансе затемнённых и ослепительно сияющих гладких плоскостей, в шокирующем сочетании золотых силуэтов и холодных зеркал, в том, как увязывались друг с другом массивы необработанного стекла и типовые предметы мебели, было немало интригующего.

Принципиальный поворот заключался в другом. Вдохновляясь практикой поп-арта, Эржебет обратилась к совершенно иному материалу - пенопласту. Казалось бы, имидж последнего как чего-то легковесного, способного при первом прикосновении до неузнаваемости измениться, превратиться в ничто, почти исчезнуть, и, конечно, апробированная обществом функциональная связь с дизайном могут отвратить от него любого скульптора. Но Шаар буквально влюбилась в этот материал, придав ему своеобразную структуру с энергичным блоковым разрешением и эстетической белоснежностью колорита. 6)

Сначала эти странные для многих коллег мастера опусы и последовавшие за ними попытки Шаар использовать в своих монументальных решениях пенопласт встречались весьма скептически. Однако постепенно рисующиеся в просвете лёгких арок фигуры молодых девушек всё чаще воспринимались как выразительный элемент природного пейзажа. Одно из таких произведений - возникающая подобно романтическому видению среди зелёного партера Балатона скульптура «Юность» - вобрало в себя поэтическую меланхолию ещё только начинающего жить молодого человека. Впрочем, получив поддержку в архитектуре, эта по-своему тонко связанная с эстетикой поп-арта символическая композиция ощущается и как некий скол вечности.

Мысль о сложных отношениях последней с современностью в творчестве Эржебет Шаар в последние годы её жизни явно доминировала. Шедшие по разным линиям эксперименты обрели точку схода в самом значительном проекте скульпто- 
ра - музейном комплексе «Улица» (1974-1975). Своеобразие замысла Шаар читается уже в его принципиальной ориентации. Череда дверей и окон с размещёнными в их проёмах бюстами выдающихся деятелей истории и искусства, множество выдвинутых вперёд символических фигур - всё это остаётся в сознании как зрелище бесконечности. Одни ощущают эту необычную совокупность как олицетворение неисчерпаемость жизни, другие, напротив, - как мемориал ушедшему. Но больше всего творение Шаар утверждается в сознании как живая элегия памяти.

Немало дискуссий вызывают и созданные ею символические женские образы. Так напоминающий современную моду рисунок бровей, украшения, причудливые очертания причёски - всё это лишь обостряет вид выполненных из пенопласта, но не лишённых классических аллюзий фигур. Имеющие ретроспективное происхождение, но в то же время обращённые к нашим дням акценты придают этим созерцательно-отрешённым образам черты экспрессии.

Кардинально отличное от преобладавшего в венгерской скульптуре 1960-1970 годов направления увлечение поп-артом усилило творческую активность её ведущих мастеров, придав их работе новые черты. Подтверждая индивидуальную неповторимость национального романтизма, расширяя его гражданский и философский контекст, оно вместе с тем сделало одной из главных своих тем соотношение образа человека с принадлежащим современности и истории предметным антуражем. Это позволило в итоге преодолеть монополию фигуративности. В лучших произведениях корифеев венгерской скульптуры Имре Варги и Эржебет Шаар романтическая концепция судьбы личности и судьбы человечества неотделима от инспирированного поп-артом видения пространства и материала.

Своеобразная выразительность вынесенных в пространство и имеющих характерные признаки поп-арта объектов опровергает восприятие этого направления как скоротечного и малоэффективного эксперимента. Усвоение его открытий играет активную роль в период, когда меняется представление о монументальном и камерном, складываются приемы единой режиссуры скульптуры, архитектуры, дизайна.

\section{БИБЛИОГРАФИЯ}

1. Светлов И.Е. Скульптура Народной Венгрии. М.: Наука, 1970.

2. Светлов И.Е. Традиции и новаторство в изобразительном искусстве социалистических стран М.: Наука, 1986.

3. Советско-венгерские связи в художественной культуре / Сост. и отв. ред. И.Е. Светлов, Л.П. Солнцева. М.: Наука, 1975.

4. Современная венгерская скульптура. Каталог выставки в ГМИИ им. А.С. Пушкина / вступ. ст. Ю. Бараньи, И. Светлова. М.: Советский художник, 1972.

5. Современное венгерское искусство и литература / отв. ред. И. Светлов, В. Середа. Государственный институт искусствознания. СПб.: Алетейя, 2005.

6. Светлов И. Скульптор Имре Варга // Творчество. 1976. № 4. С. 21-23

7. Светлов И. Эржебет Шаар: стремления и итоги // Искусство. 1976. № 7. С. 50-53.

8. Nickel Christa. Imre Varga im Gespräch. Budapest, 1995.

9. Schaār Erzsēbet Szobrāsz-Mủvēsz Kiāllītāsa Múcsarnok. Budapest, 1970. 